\title{
Rainfall and Elevation Influence the Local-Scale Distribution of Tree Community in the Southern Region of Western Ghats Biodiversity Hotspot (India)
}

\author{
Shijo Joseph, ${ }^{1,2,3}$ K. Anitha, ${ }^{2,4}$ V. K. Srivastava, ${ }^{1}$ Ch. Sudhakar Reddy, ${ }^{1}$ A. P. Thomas, ${ }^{4}$ \\ and M. S. R. Murthy ${ }^{1}$ \\ ${ }^{1}$ Forestry and Ecology Division, National Remote Sensing Centre, Indian Space Research Organization, Hyderabad 500 625, India \\ ${ }^{2}$ Conservation Research Group (CRG), St. Albert's College, Kochi 682 018, India \\ ${ }^{3}$ Forests and Environment Program, Center for International Forestry Research (CIFOR), Bogor 16115, Indonesia \\ ${ }^{4}$ Advanced Centre of Environmental Studies and Sustainable Development, School of Environmental Sciences, \\ Mahatma Gandhi University, Kerala 686 560, India \\ Correspondence should be addressed to Shijo Joseph, shijonrsa@gmail.com
}

Received 18 October 2011; Revised 22 February 2012; Accepted 23 February 2012

Academic Editor: Guofan Shao

Copyright (C 2012 Shijo Joseph et al. This is an open access article distributed under the Creative Commons Attribution License, which permits unrestricted use, distribution, and reproduction in any medium, provided the original work is properly cited.

The present study characterises the tree communities with respect to topographic and climatic variables and identifies the most important environmental correlate of species richness in the southern region of Western Ghats Biodiversity Hotspot, India. Digitally derived environmental variables in combination with tree species richness information were analysed using Canonical Correspondence Analysis (CCA) to characterise the communities. Multiple regression technique based on stepwise backward elimination was used to identify the most important environment correlate of species richness. Canonical correspondence analysis results in six major tree communities along the first and second axes. Rainfall is the dominant environmental gradient influencing vegetation patterns on the first CCA axis while elevation showed the highest correlation with the second CCA axis. Backward elimination regression technique yielded rainfall as the most important environmental correlate of species richness. Results were in agreement with the observations in the Neotropics that rainier areas maintain high species diversity.

\section{Introduction}

Tropical forests are unique in many aspects such as high diversity [1], high standing biomass and carbon storage [2], and global net primary productivity [3]. There have been many attempts to understand the structural complexity and species diversity of these ecosystems spanning over three decades $[1,4-11]$. While a complete perception of the tropical forest still remains a challenge, the degradation and deforestation is hastening on the other side. Information on distribution of tree communities along environmental gradients has vital role in understanding their ecology as well as their conservation and management. Quantification of such species-environment relationships yields valuable insights into ecological processes such as resource partitioning and niche differentiation [12] and forms the core of predictive geographical modelling in ecology [13]. Today's concern about biodiversity losses and ecosystem services suggest that forest classifications based on species composition are needed, along with the information on how many species are shared between different forest types. This information in combination with the key environmental correlates is important for natural reserve area planning and management under global change scenarios.

The importance of climate to map animal and plant distribution was recognized during the early stages of nineteenth century [14]. Climate in combination with other physical elements of the environment has been used to derive vegetation patterns at the global scale $[15,16]$. More recently, studies have revealed regional variability in vegetation types with respect to topography, seasonality, soil types, and water and nutrient availability [17-22]. However, most of these 
studies were carried out in the Neotropics in comparison with the Old World tropics [23]. Notable exceptions include studies conducted by Pascal [24], Gimaret-Carpentier et al. [25, 26], Davidar et al. [27, 28], and Joseph et al. [12]. Similarly, most of the studies were conducted in the tropical humid forests ignoring the other tropical formations, particularly dry forests. Clearly, these patterns reflect the biases that characterize tropical biology [29].

Western Ghats, located near to the western coastline of India, is one of the "Hottest Hotspots" of biological diversity in the Old World tropics [8]. It contains more than 30\% of all plant and vertebrate species found in India, in less than $6 \%$ of the country's landmass. It is also recognized as one among the 200 globally most important ecoregions [30]. Of the four thousand species of flowering plants known from the Western Ghats, 1500 are endemic [31]. In spite of these striking statistics, biodiversity in the Western Ghats is threatened by a range of anthropogenic pressures. Menon and Bawa [32] estimated that between 1920 and 1990 forest cover in the Western Ghats declined by $40 \%$, resulting in a fourfold increase in the number of fragments and an $83 \%$ reduction in size of forest patches. The yearly rate of forest loss has been estimated at $0.57 \%$ [32], $0.9 \%$ [33], and $1.16 \%$ [34] in unprotected areas while $0.04 \%$ in protected areas [35]. This highlights, the need for more studies on regional patterns of diversity and its drivers, as data on partitioning of tropical vegetation types under different climatic and topographic gradients supply valuable inputs for conservation planning [36, 37]. On a macroscale (entire Western Ghats), the diversity and species richness are largely attributed to seasonality [28] while the mesoscale assessment showed that the diversity is a correlate of rainfall [37]. Further to this, the present study is an attempt to identify the highest environmental correlate species diversity at the local scale.

\section{Materials and Methods}

2.1. Study Area. Anamalai region located in the southern Western Ghats is known to be active zones of speciation and localized centres of endemism $[31,38]$ due to its varied topography and microclimatic regimes (Figure 1). It is also considered as one of the 25 microcentres of diversity in the Indian Subcontinent [39]. The overall terrain is hilly with altitude ranging from $220 \mathrm{~m}$ at the foothills in the north-east to $2550 \mathrm{~m}$ (in the Grass Hills area) in the south-west. The annual rainfall varies from $500 \mathrm{~mm}$ in the rain shadow eastern slopes to $5000 \mathrm{~mm}$ in the west. Mean daily temperature varies from $<5^{\circ} \mathrm{C}$ in the winter at elevations above $2000 \mathrm{~m}$ to nearly $40^{\circ} \mathrm{C}$ in the eastern plain in the summer. Ecoclimatically, the area is considered as a miniature of the Western Ghats biodiversity hotspots and harbors all major forest types found in the Western Ghats [35]. The objectives of the present study are to outline the tree communities under diverse climatic and topographic gradients in the Anamalai region and to identify the important environmental correlate of the species richness in the area.
2.2. Field Sampling and Environmental Data. A stratified transect survey was adopted for the study. The strata were delineated considering the long-term climatic observations and altitudinal variation in the study area.

Though there were a few weather stations scattered over the area, the datasets available from these stations were for a maximum of five years [40]. Therefore the present study used a global database called Worldclim [41]. This is the station data during the period of 1950-2000 and was interpolated to monthly climate surfaces at $1 \mathrm{~km}$ spatial resolution using a thin-plate smoothing spline algorithm with latitude, longitude, and elevation as independent variables [41]. The annual average temperature $\left({ }^{\circ} \mathrm{C}\right)$ and rainfall $(\mathrm{mm})$ were calculated from the monthly datasets (Figure 2 ). The topographic variables such as elevation $(\mathrm{m})$, slope (angle of inclination in degrees), and aspect (direction of slope in degrees) were derived from Shuttle Radar Topographic Mission (SRTM) data (Figure 2). Further, the SRTM digital elevation model was placed over climatic data to study the changes in climatic parameters with respect to elevation. Four strata were delineated and transects sampling was conducted in these strata. Circular plots of $10 \mathrm{~m}$ radius (plot size-314 $\mathrm{m}^{2}$ ) were laid on every $200 \mathrm{~m}$ interval along transects (Figure 1). In each plot, all woody plants with $\geq 10 \mathrm{~cm} \mathrm{DBH}$ (Diameter at Breast Height, $1.3 \mathrm{~m}$ ) were identified at species level, their individuals counted, and DBH measured using a tape. A total of 19 transects (thirteen $2 \mathrm{~km}$ transects + six $1 \mathrm{~km}$ transects) with 179 sampling plots were surveyed. In addition, 27 sampling plots have been collected randomly especially in shola forest and evergreen patches since one-or two-kilometer continuous stretch was not available for these habitats. Thus, in total 206 sample plots with an area of 65 ha (which is approximately 0.001 of the total area) were surveyed.

2.3. Data Analysis. In order to investigate the relationships between species richness and environmental variables, a Canonical Correspondence Analysis (CCA) was employed [42] using the software PC-ORD [43]. CCA is a direct gradient ordination technique to cluster species abundance with environmental variables [44]. The first step of CCA was to summarize the main variation in the species data by ordination. This was done by constructing an axis such that the species data optimally fit Gaussian response curves (Gaussian ordination) according to the following equation:

$$
E\left(Y_{i k}\right)=C_{k} \exp \left[\frac{1}{2}\left(\frac{\left(X_{i}-U_{k}\right)^{2}}{t_{k}^{2}}\right)\right],
$$

where $Y_{i k}$ is the abundance of species $k$ at site $i$ and $E\left(Y_{i k}\right)$ denotes the expected (average) value of $Y_{i k}$ at site $i$ that has score $X_{i}$, on the ordination axis. The parameters for species $k$ are $C_{k}$, the maximum of that species' response curve; $U_{k}$, the mode or optimum (i.e., the value of $x$ for which the maximum is attained); $t_{k}$, the tolerance, a measure of ecological amplitude.

The second step was to relate the ordination axis to the environmental variables by calculating correlation 


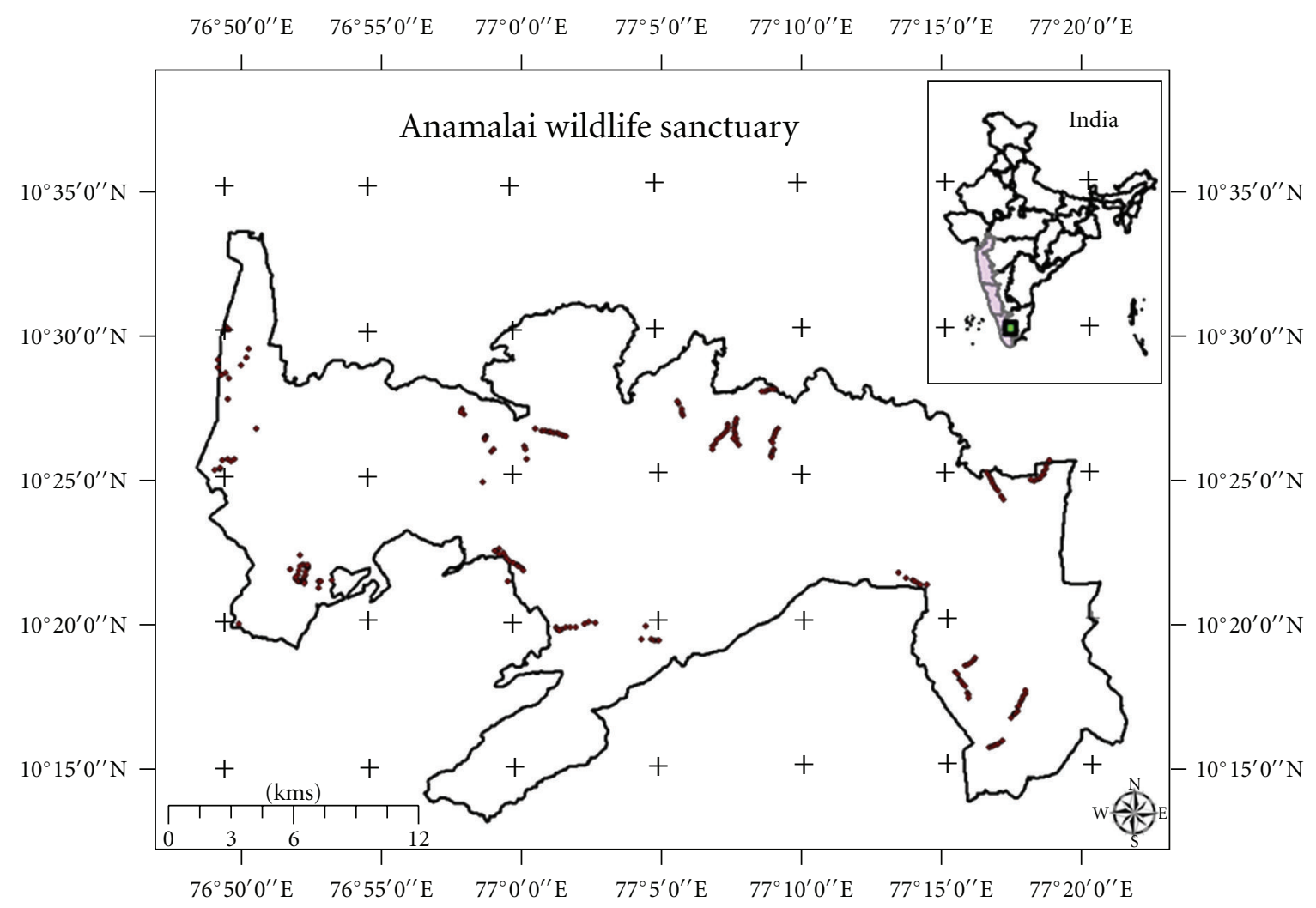

FIGURE 1: Location of the Anamalai wildlife sanctuary in the Western Ghats Biodiversity Hotspot (India). The dots represent the sampling locations.

coefficients or by multiple regression [45] of the site scores on the environmental variables by the following equation:

$$
X_{i}=b_{0}+\sum_{j=1}^{q} b_{j} z_{i j}
$$

where $b_{0}$ is the intercept and $b_{\mathrm{j}}$ is the regression coefficient for environmental variable $j . z_{i j}$ is the value of environmental variable $j$ at site $i$ and $q$ is the number of environmental variables.

Finally, the weighted average of a species distribution $(k)$ with respect to an environmental variable $(j)$ was defined as the average of the values of that environmental variable at those sites at which that species occurs, the weighting of each site being proportional to species abundance, that is,

$$
\bar{z}_{k j}=\sum_{i=1}^{n} \frac{Y_{i k} Z_{i j}}{Y_{+k}} .
$$

The weighted average indicates the "center" of a species' distribution along an environmental variable, and differences in weighted averages between species indicate differences in their distributions along that environmental variable.

As required by CCA, the data is set into two distinct matrices: the species matrix and the matrix of environment variables. The species matrix contained number of species per plot, and the environmental variables matrix consisted elevation, slope, aspect, temperature, and rainfall.
The tree communities obtained after Canonical Correspondence Analysis were assessed their compositional attributes. Here, the compositional attributes refer to species richness, diversity, dominance, stand density, and average basal area of each community. For calculating diversity, two indices were used in addition to simple species richness (number of species). The first one was Shannon-Weiner diversity index (4) [46] and the second was Simpson diversity index (6) [47]. The latter was calculated from Simpson dominance index (5). The average basal area was calculated from the diameter of the stem at breast height using (7):

Shannon-Weiner diversity index:

$$
H^{\prime}=-\sum p_{i} \ln p_{i},
$$

where $H^{\prime}$ is the measure of diversity and $p_{i}$ is the proportion of the total sample belonging to the $i$ th species.

Simpson dominance index

$$
D=\sum p_{i}^{2},
$$

where $D$ is the Simpson index of dominance and $p_{i}$ is the proportional individuals of species $i$ in the community.

Simpson diversity index:

$$
1-D=1-\sum p_{i}^{2},
$$




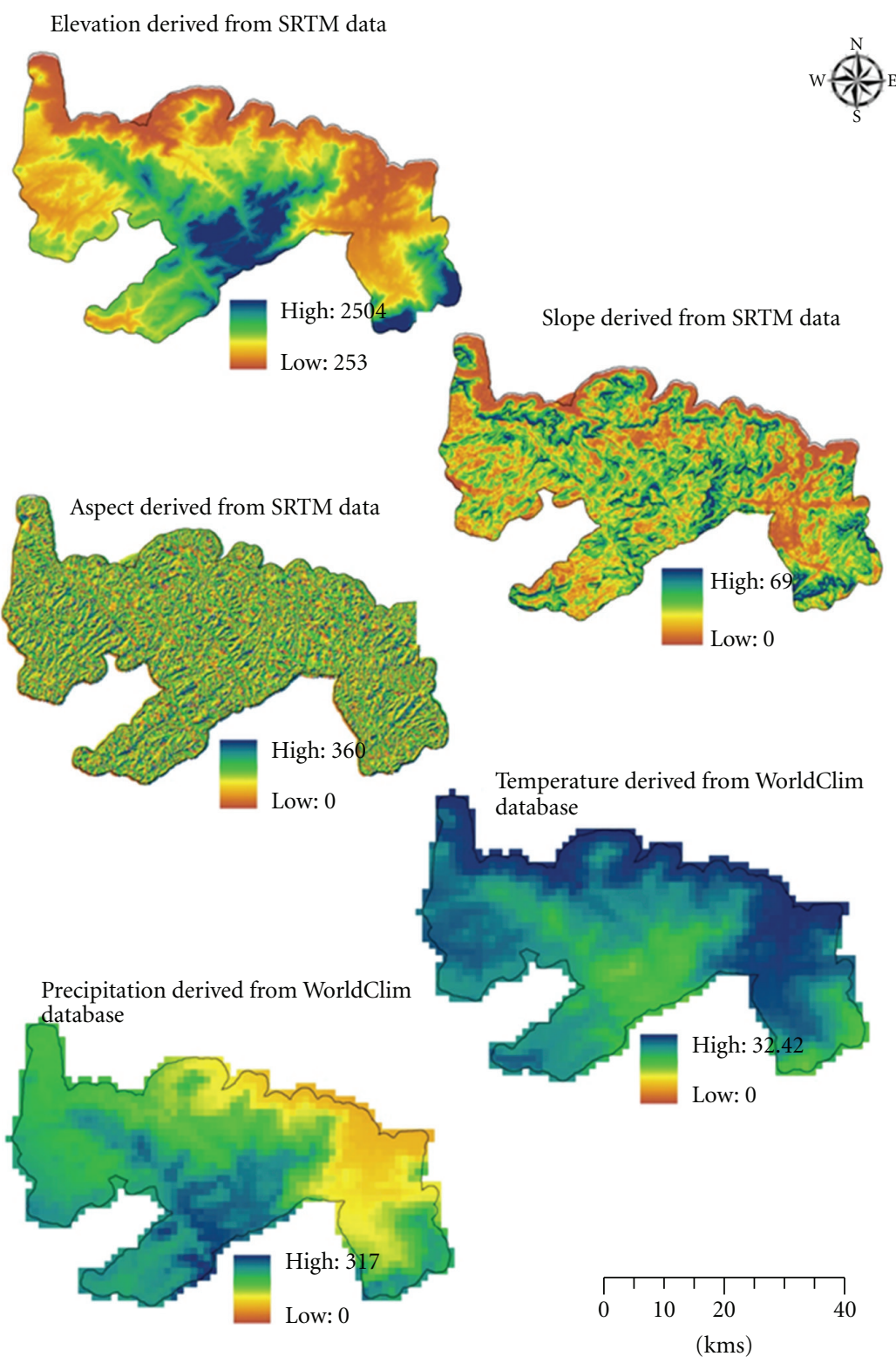

FIgURE 2: Topographical (elevation (m), slope (degrees) and aspect (degrees)) and climatic gradients (temperature $\left({ }^{\circ} \mathrm{C}\right)$ and precipitation $(\mathrm{cm})$ ) in Anamalai wildlife sanctuary, India (topographical variables are derived from SRTM data and climatic variable are derived from 50 year average WorldClim datasets).

where $1-D$ is Simpson's index of diversity.

$$
\text { Basal area }=\frac{(\mathrm{DBH})^{2}}{4 \pi},
$$

where $\mathrm{DBH}$ is diameter at breast height.

Multiple linear regression analysis was conducted to identify the most important environmental correlates of species richness. A stepwise backward elimination approach was adopted in which the analysis started with all the continuous variables and eliminated the least significant variable in each progressive step. The variables were removed if the probability of " $F$ " exceeds 0.05 . The species richness was the dependent variable and elevation, slope, aspect, rainfall, and temperature were the independent variables. The analysis was carried out using the software SPSS [48].

\section{Results}

A total of 169 tree species were observed during the present study. Among these, Maesa indica had the highest number of individuals (73) followed by Anogeissus latifolia (56) and Croton oblongifolius (55). The phytodiversity assessment also showed that the sanctuary is a hub of many endemic and threatened species which include Aglaia tamilnadensis, Dysoxylum malabaricum, Myristica malabarica, Syzygium malabaricum, and Vernonia travancorica. 
3.1. Tree Communities. Canonical correspondence analysis was performed for 169 species recorded on 206 plots with 5 environmental variables to understand the tree community composition of the study area. The ordination diagram obtained after Canonical correspondence analysis is shown in Figure 3. The eigenvalues for the first three CCA axes were $0.749,0.523$, and 0.304 , respectively. The cumulative percentage variance accounted for those axes was $16.0 \%$ (7.6, 5.2, and 3.2, resp.), indicating that a considerable amount of "noise" still remained unexplained. In fact, the CCA produced high correlations between species and environmental variables for these axes $(0.94,0.88$, and 0.74 , resp.). The first ordination axis was highly correlated, in descending sequence, with rainfall, temperature, elevation, and slope (Table 1). The second ordination axis has shown high correlation with elevation and temperature while the third ordination axis is correlated with slope. The weighted correlations between environmental variables showed strong interrelationships, especially between elevation and climatic variables (temperature and rainfall). Segregation of plant communities along the noted gradients was also observed. The left side of the ordination space was dominated with communities which are primarily evergreen species whereas the right side was occupied by deciduous species (Figure 3 ). The details of the communities are further explained below.

3.1.1. Evergreen Community. This group is characterized by the species such as Vateria indica, Persea macrantha, Palaquium ellipticum, Eugenia calophyllifolia, and Macrantha roxburgii. This species assemblage more or less corresponds to west coast tropical evergreen forest (1A/C4) of Champion and Seths [51] classification of Indian forests. This forest occurs in relatively undisturbed area between altitudes of 900-1500 msl. They are embarked by higher humidity, lower temperature, lower understory, low canopy openings, and high leaf litter.

3.1.2. Montane Shola Community. The major species in shola forests are Syzygium cumini, Vitex leucoxylon, Dysoxylum malabaricum, Cinnamomum sulphuratum, and Eugenia calophyllifolia. This group corresponds to southern montane wet temperate forest $(11 \mathrm{~A} / \mathrm{C} 1)$ as per Champion and Seth's classification. It occurs at an elevation of more than $1500 \mathrm{~m}$. Annual rainfall in these areas is about $5000 \mathrm{~mm}$ while annual temperature is approximately $15^{\circ} \mathrm{C}$. Geographically the area can be distinguished from the steep slopes and mountain folding.

3.1.3. Semi-Evergreen Community. These formations are distinguished by species such as Nephelium longana, Palaquium ellipticum, Vateria indica, Terminalia bellirica, and Vitex altissima and correspond to west coast tropical semievergreen forest $(2 \mathrm{~A} / \mathrm{C} 2)$. This is found at altitudinal ranges of 700-900 $\mathrm{m}$ and relatively high rainfall areas.

3.1.4. Moist Deciduous Community. They are characterized by the presence of species such as Anogeissus latifolia, Maesa indica, Albizia odoratissima, Terminalia crenulata, and
Ziziphus oenoplia and match up with Champion and Seth's southern moist mixed deciduous forest $(3 \mathrm{~B} / \mathrm{C} 2)$. This forest community occurs at altitudes of 500-700 msl with relatively low rainfall zones.

3.1.5. Dry Deciduous Community. This group is a composition of Anogeissus latifolia, Dalbergia latifolia, Albizia amara, Maesa indica, and Terminalia paniculata and corresponds to southern dry mixed deciduous forest (5A/C3). This is found on areas where altitude ranges from 400 to $600 \mathrm{~m}$ with very low rainfall.

3.1.6. Thorny Scrub Community. This community is formed in areas where human disturbance is maxima and rainfall is less. They occur at lower altitudes $(<400 \mathrm{~m})$ with thorny species such as Albizia amara, Gyrocarpus americanus, Catunaregam spinosa, Acacia planifrons, and Limonia crenulata. It corresponds to southern thorn scrub as per Champion and Seth's [51] classification of Indian forest. Canopy openings and open spaces are characteristics of the area. Cattle grazing and firewood collection is frequent in the area.

3.2. Compositional Attributes of Tree Communities. The compositional attributes of tree communities in Anamalai region is given in Table 2. Evergreen community showed maximum species richness, that is, 81 tree species. Both the diversity indices (Shannon and Simpson) showed that evergreen forest was highly diverse in comparison with other forest types, whereas the dominance in the evergreen forest was lower. The highest dominance was observed in dry deciduous forest (Simpson dominance index-0.093) followed by moist deciduous forest $(0.075)$. The stand density was higher at shola forest ( 446 individuals per hectare) while average basal area was higher in semi-evergreen forest $\left(62.3 \mathrm{~m}^{2} / \mathrm{ha}\right)$.

3.3. Environmental Correlates of Species Richness. The assessment of species richness from environmental variables yielded the following model (Table 3 ). The model fit was 0.50 ( $F$ 39.82, $P<0.05$ ). Though the overall model was significant, the values of " $t$ " and its significance indicate that each of these variables was not significantly contributing to the overall model. Therefore, the variable having the least partial correlation coefficient (in this case aspect) was eliminated from the model. The model was then refitted with all other variables and this procedure was repeated until only statistically significant variables are left in the model. In this case, only one variable was found to be a significant predictor of species number, that is, rainfall (8). Because of the strong correlation among variables (Table 2 ), this was not surprising, but it also means that it is difficult to disentangle the separate effects of the independent variables. The model fit was $0.485(F 192.91, P<0.05)$ :

Species Richness $=0.004 *$ Rainfall -1.311 . 
TABLE 1: Canonical correspondence analysis of 169 species in 206 plots in Anamalai wildlife sanctuary. Matrix presents intraset correlation between environmental variables and first three axes and weighted correlations between environmental variables.

\begin{tabular}{lcccccccc}
\hline Variable & Axis 1 & Axis 2 & Axis 3 & Elevation & Slope & Aspect & Precipitation & Temperature \\
\hline Elevation & -0.662 & 0.734 & 0.063 & 1 & 0.422 & 0.181 & 0.757 & -0.946 \\
Slope & -0.542 & 0.016 & 0.806 & 0.422 & 1 & 0.027 & 0.48 & -0.436 \\
Aspect & -0.186 & 0.268 & -0.123 & 0.181 & 0.027 & 1 & 0.186 & -0.175 \\
Rainfall & -0.986 & 0.139 & -0.052 & 0.757 & 0.48 & 0.186 & -0.805 \\
Temperature & 0.715 & -0.619 & -0.131 & -0.946 & -0.436 & -0.175 & -0.805 & 1 \\
\hline
\end{tabular}

TABLE 2: The different compositional attributes such as species richness, diversity indices, dominance index, stand density per hectare, and average basal area per hectare with respect to tree communities in Anamalai wildlife sanctuary, India.

\begin{tabular}{|c|c|c|c|c|c|c|}
\hline \multirow{2}{*}{ Parameters } & \multicolumn{6}{|c|}{ Tree community } \\
\hline & Evergreen & Shola & Semi evergreen & MDF & DDF & Thorny scrub \\
\hline No. of species & 81 & 17 & 55 & 32 & 18 & 27 \\
\hline Shannon diversity index & 4.175 & 3.000 & 3.450 & 3.214 & 2.982 & 3.121 \\
\hline Simpson index of dominance & 0.021 & 0.071 & 0.054 & 0.075 & 0.093 & 0.059 \\
\hline Simpson index of diversity & 0.979 & 0.929 & 0.946 & 0.925 & 0.907 & 0.941 \\
\hline Stand density/ha. & 347 & 446 & 276 & 192 & 212 & 69 \\
\hline Avg. Basal area/ha. & 31.4 & 41.4 & 62.3 & 27.2 & 13.2 & 2.13 \\
\hline
\end{tabular}

MDF: moist deciduous forest, DDF: dry deciduous forest.

TABLE 3: Overall regression model of species richness from environmental variables in Anamalai wildlife sanctuary $\left(R^{2}-0.50\right.$, $F-39.82, d f 1-5, d f 2-199$ and $P-2.98 E-28)$.

\begin{tabular}{lcccc}
\hline Variable & Coefficient & Std. error & $t$ & Significance \\
\hline Intercept & 3.354 & 4.857 & 0.690 & 0.491 \\
Elevation & -0.002 & 0.001 & -1.737 & 0.084 \\
Slope & 0.026 & 0.023 & 1.126 & 0.262 \\
Aspect & 0.001 & 0.001 & 0.628 & 0.531 \\
Rainfall & 0.004 & 0.000 & 8.248 & 0.000 \\
Temperature & -0.135 & 0.134 & -1.003 & 0.317 \\
\hline
\end{tabular}

\section{Discussion}

4.1. Tree Communities. The present study in Anamalai region of southern part of Western Ghats identified six tree communities, namely, tropical evergreen, montane shola, semi-evergreen, moist deciduous, dry deciduous, and thorny scrub along rainfall and elevation gradients (Table 4). Cumulative proportions of variance of the species data were quite low. However, ter Braak [52] considers low percentage of unexplained variance as normal in vegetation data, and this fact does not weaken the significance of species-environment relationships. Our study revealed that rainfall has a profound role in shaping up the vegetation of the area along with topography. For instance, the low rainfall $(<800 \mathrm{~mm} / \mathrm{yr})$ and low elevation $(<400 \mathrm{~m})$ areas are characterized by thorny scrub community; low rainfall and medium elevation areas (400-600 m) by dry deciduous community; medium rainfall areas $(800-2000 \mathrm{~mm} / \mathrm{yr})$ with an altitude range of $500-$ $700 \mathrm{~m}$ by moist deciduous community; high rainfall areas (2000-3000 mm/yr) with medium altitude (700-900 m) by semievergreen community; high rainfall areas with high elevation range (900-1500) by evergreen community; very high rainfall areas $(>3000 \mathrm{~mm} / \mathrm{yr})$ with very high elevation $(>1500 \mathrm{~m}$ ) and slope by montane shola community.

Though there is a clear distinction between evergreen and deciduous communities in the ordination space, the boundary within each of these communities (e.g., the distinction among moist deciduous, dry deciduous and thorny scrub) is fuzzier. This may be because of the fact that the species composition is not significantly different among these communities. Moreover, the thorny scrub is considered as a degraded state of deciduous system [51]. The gradual transition from one vegetation type to an other with respect to changes in environmental gradients has been reported in other parts of Western Ghats as well $[37,53]$.

4.2. Compositional Attributes. Shannon-Weiner and Simpson diversity indices indicated high diversity from the area similar to previous observations from the Western Ghats $[12,49,50,54]$. For example, Ayyappan and Parthasarathy [54] reported Shannon diversity index of 3.926 in evergreen habitats of Anamalai hills which was slightly lower than the present estimate (4.175). Tree density (stand density) in evergreen forest was 347 trees/ha which was slightly lower than the mean tree density (419 trees/ha) observed for Western Ghats closed-canopy evergreen forest [55]. The mean basal area in the wet forest was $45.03 \mathrm{~m}^{2} /$ ha which 
TABLE 4: The tree communities and their distribution range with respect to environmental variables in Anamalai wildlife sanctuary, Western Ghats, India.

\begin{tabular}{lccc}
\hline Forest type & Temperature $\left({ }^{\circ} \mathrm{C}\right)$ & Rainfall $(\mathrm{mm})$ & Elevation $(\mathrm{m})$ \\
\hline Evergreen forest & $15-19$ & $3000-4500$ & $900-1500$ \\
Montane shola forest & $<15$ & $>4500$ & $>1500$ \\
Semi-evergreen forest & $19-22$ & $2200-3000$ & $700-900$ \\
Moist Deciduous forest & $22-27$ & $1400-2200$ & $500-700$ \\
Dry Deciduous forest & $27-31$ & $800-1400$ & $400-600$ \\
Thorny scrub forest & $>31$ & $<800$ & $<400$ \\
\hline
\end{tabular}

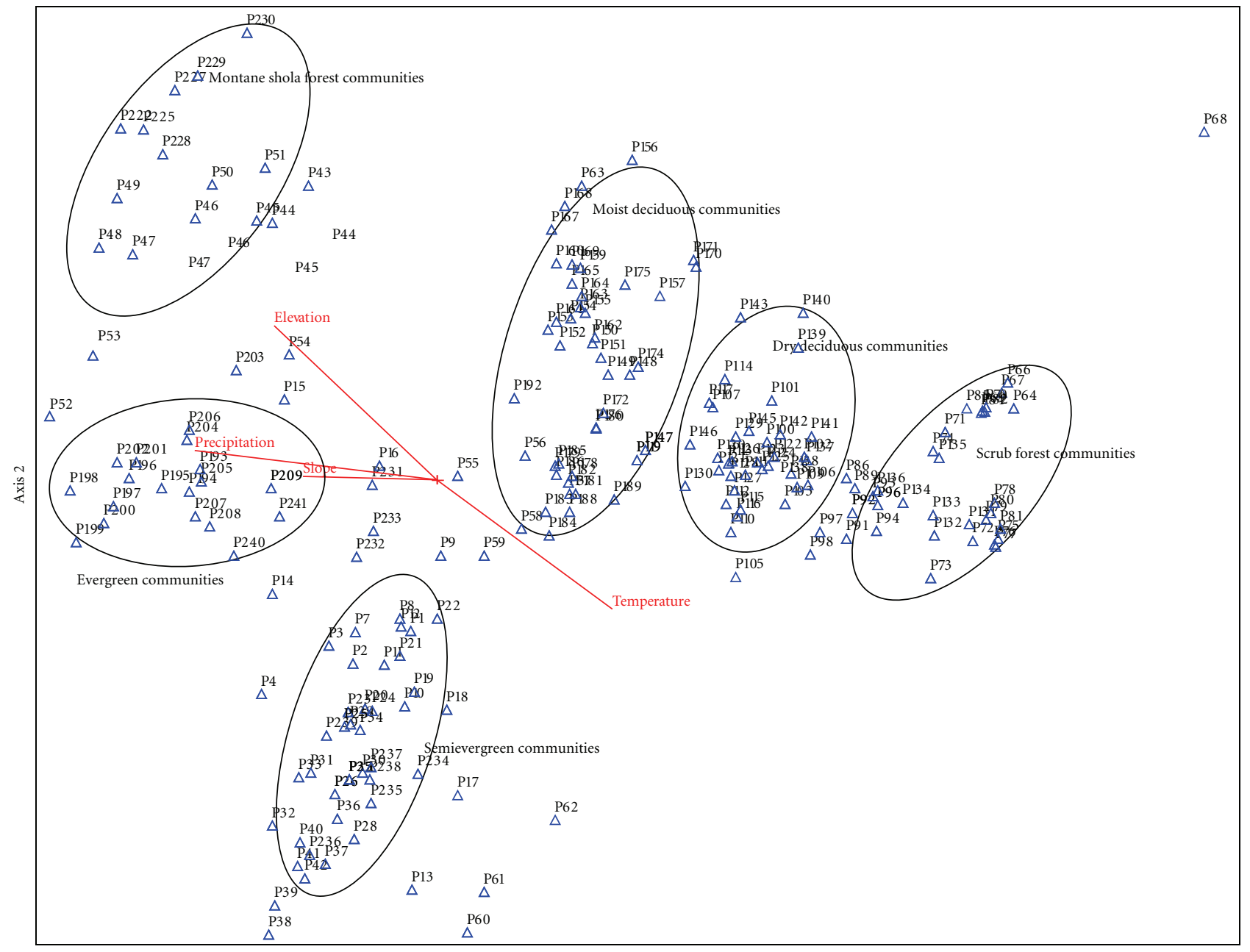

Axis 1

FIgURE 3: CCA ordination diagram (Axis 1 by Axis 2) with plots (scattered points) and environmental variables (lines) in Anamalai wildlife sanctuary. Each circle represents partitioning of vegetation communities along environmental gradients.

was higher than the previous reports $\left(36.26 \mathrm{~m}^{2} / \mathrm{ha}\right)[54]$ and Pantropical average $\left(32 \mathrm{~m}^{2} / \mathrm{ha}\right)$ [56]. But it was not significantly different from other parts of the Western Ghats. For example, Giriraj et al. [49] reported $47.01 \mathrm{~m}^{2} /$ ha for Kalakad-Mundanthurai Tiger Reserve, Ganesh et al. [57] reported $42.03 \mathrm{~m}^{2} /$ ha at Kakachi, and Pascal and Pelissier [58] reported $39.7 \mathrm{~m}^{2} /$ ha at Uppangala. The lowest basal area observed for thorny scrub forest was in correspondence with the similar trend in Mudumalai wildlife sanctuary
[12]. Assessment of different compositional attributes of tree communities in the Anamalai region indicates that the area is an essential element in the global biodiversity register in general and the Western Ghats in particular.

4.3. Environmental Correlates. Rainfall is found to be the most important environmental correlate of species richness in the Anamalai region. At macroscales, Davidar et al. [28] 
reported that length of dry season or seasonality drive wet evergreen forest beta diversity. Similarly, studies using pollen grains also pointed out that seasonality is the primary driver that decides the composition of vegetation communities throughout the Western Ghats [59]. However, the mesoscale assessment showed rainfall as the primary driver of species richness [37] in concordance with the findings of the present study at the local scale. Gentry [60,61], Aplet et al. [62] and Pitman et al. [63] also made similar observations in the Neotropics that rainfall is a primary factor influencing tropical forest diversity. Though this generalization is applicable to Western Ghats Biodiversity Hotspot, it may not hold true for all the Old World tropics. In tropical Asia, high rainfall areas such as Mt. Cherrapunji, Assam, often have relatively low plant species richness [61]. In tropical Africa, two high rainfall sites $(>5000 \mathrm{~mm} /$ year) in south Western Cameroon have only marginally more species in 0.1 ha samples than do samples from northeastern Gabon that receive $<2000 \mathrm{~mm}$ of annual rainfall. Moreover, a more monsoonal climate site in Nigeria had many fewer species than the Gabon sites despite having similar rainfall values [36]. Thus, it seems likely that the generalization that diversity increases linearly with rainfall applies only in the special cases of the Neotropics and the Old World tropics.

\section{Conclusion}

The present study on plant communities with respect to climatic and topographic gradients at the local scale leads into valuable insights on resource partitioning and niche differentiation of an area. High rainfall zones favoured the luxurious growth of evergreen communities whereas low rainfall areas favoured deciduous communities. Altitudinal gradient was prevalent in partitioning these major vegetation communities into subcommunities such as montane shola, evergreen, semievergreen, moist deciduous, dry deciduous and thorny scrub. Regression based on backward elimination indicated that rainfall is the most important correlate of species richness. The result was in agreement with the observations in the Neotropics that the rainier areas maintain high species diversity.

\section{Acknowledgments}

Authors are sincerely thankful to Director and Deputy Director, National Remote Sensing Centre and Dean and PI, WII-NNRMS Project, Wildlife Institute of India for their encouragement; Ministry of Environment and Forests, Government of India for funding support and Tamil Nadu Forest Department for assistance during the field work.

\section{References}

[1] N. J. B. Kraft, R. Valencia, and D. D. Ackerly, "Functional traits and niche-based tree community assembly in an amazonian forest," Science, vol. 322, no. 5901, pp. 580-582, 2008.

[2] G. B. Bonan, "Forests and climate change: forcings, feedbacks, and the climate benefits of forests," Science, vol. 320, no. 5882, pp. 1444-1449, 2008.
[3] C. L. Sabine, M. Heimann, P. Artaxo et al., "Current status and past trends of the global carbon cycle," in The Global Carbon Cycle: Integrating Humans, Climate and the Natural World, C. B. Field and M. R. Raupach, Eds., pp. 17-44, Island Press, Washington, DC, USA, 2004.

[4] S. P. Hubbell, "Tree dispersion, abundance, and diversity in a tropical dry forest," Science, vol. 203, no. 4387, pp. 1299-1309, 1979.

[5] S. P. Hubbell, The Unified Neutral Theory of Biodiversity and Biogeography, Princeton University Press, Princeton, NJ, USA, 2001.

[6] R. Condit, R. Sukumar, S. P. Hubbell, and R. B. Foster, "Predicting population trends from size distributions: a direct test in a tropical tree community," American Naturalist, vol. 152, no. 4, pp. 495-509, 1998.

[7] R. Condit, "Spatial patterns in the distribution of tropical tree species," Science, vol. 288, no. 5470, pp. 1414-1418, 2000.

[8] N. Myers, R. A. Mittermeler, C. G. Mittermeler, G. A. B. Da Fonseca, and J. Kent, "Biodiversity hotspots for conservation priorities," Nature, vol. 403, no. 6772, pp. 853-858, 2000.

[9] C. Wills, K. E. Harms, R. Condit et al., "Nonrandom processes maintain diversity in tropical forests," Science, vol. 311, no. 5760, pp. 527-531, 2006.

[10] F. Forest, R. Grenyer, M. Rouget et al., "Preserving the evolutionary potential of floras in biodiversity hotspots," Nature, vol. 445, no. 7129, pp. 757-760, 2007.

[11] J. Dengler, "A flexible multi-scale approach for standardised recording of plant species richness patterns," Ecological Indicators, vol. 9, no. 6, pp. 1169-1178, 2009.

[12] S. Joseph, C. S. Reddy, C. Pattanaik, and S. Sudhakar, "Distribution of plant communities along climatic and topographic gradients in Mudumalai Wildlife Sanctuary (southern India)," Biological Letters, vol. 45, pp. 20-33, 2008.

[13] A. Guisan and N. E. Zimmermann, "Predictive habitat distribution models in ecology," Ecological Modelling, vol. 135, no. 2-3, pp. 147-186, 2000.

[14] A. I. De Candolle, Geographique Botanique Raisonneae, Masson, Paris, France, 1855.

[15] L. R. Holdridge, Life Zone Ecology, Tropical Science Center, San Jose, Costa Rica, 1967.

[16] R. H. McArthur, Geographical Ecology: Patterns in the Distribution of Species, Harper and Row, New York, NY, USA, 1972.

[17] D. B. Clark, D. A. Clark, and J. M. Read, "Edaphic variation and the mesoscale distribution of tree species in a neotropical rain forest," Journal of Ecology, vol. 86, no. 1, pp. 101-112, 1998.

[18] C. H. Cannon and M. Leighton, "Tree species distributions across five habitats in a bornean rain forest," Journal of Vegetation Science, vol. 15, no. 2, pp. 257-266, 2004.

[19] R. Valencia, R. B. Foster, G. Villa et al., "Tree species distributions and local habitat variation in the amazon: large forest plot in eastern ecuador," Journal of Ecology, vol. 92, no. 2, pp. 214-229, 2004.

[20] F. De Bello, J. Lepš, and M. T. Sebastià, "Variations in species and functional plant diversity along climatic and grazing gradients," Ecography, vol. 29, no. 6, pp. 801-810, 2006.

[21] J. A. Gallardo-Cruz, E. A. Perez-Garcia, and J. A. Meave, “ $\beta$ diversity and vegetation structure as influenced by slope aspect and altitude in a seasonally dry tropical landscape," Landscape Ecology, vol. 24, no. 4, pp. 473-482, 2009.

[22] W. Sang, "Plant diversity patterns and their relationships with soil and climatic factors along an altitudinal gradient in the middle tianshan mountain area, Xinjiang, China," Ecological Research, vol. 24, no. 2, pp. 303-314, 2009. 
[23] R. Dirzo, "The tropics beyond species diversity: richness of biotic interactions," Ecology, vol. 87, pp. 3218-3219, 2006.

[24] J. P. Pascal, Wet Evergreen Forests of the Western Ghats of India (Ecology, Structure, Floristic Composition and Succession): Travaux de la Section Scientifique et Technique, Tome XXIII, Institut Français de Pondichery, 1998.

[25] C. Gimaret-Carpentier, D. Chessel, and J. P. Pascal, "Nonsymmetric correspondence analysis: an alternative for species occurrences data," Plant Ecology, vol. 138, no. 1, pp. 97-112, 1998.

[26] C. Gimaret-Carpentier, S. Dray, and J. P. Pascal, "Broadscale biodiversity pattern of the endemic tree flora of the western ghats (India) using canonical correlation analysis of herbarium records," Ecography, vol. 26, no. 4, pp. 429-444, 2003.

[27] P. Davidar, J. P. Puyravaud, and E. G. Leigh, "Changes in rain forest tree diversity, dominance and rarity across a seasonality gradient in the Western Ghats, India," Journal of Biogeography, vol. 32, no. 3, pp. 493-501, 2005.

[28] P. Davidar, B. Rajagopal, D. Mohandass et al., "The effect of climatic gradients, topographic variation and species traits on the beta diversity of rain forest trees," Global Ecology and Biogeography, vol. 16, no. 4, pp. 510-518, 2007.

[29] D. F. R. P. Burslem, M. A. Pinard, and S. E. Hartley, Eds., Biotic Interactions in the Tropics: Their Role in the Maintenance of Species Diversity, Cambridge University Press, Cambridge, UK, 2005.

[30] D. M. Olson and E. Dinerstein, "The global 200: a representation approach to conserving the earth's most biologically valuable ecoregions," Conservation Biology, vol. 12, no. 3, pp. 502-515, 1998.

[31] N. C. Nair and P. Daniel, "The floristic diversity of the Western Ghats and its conservation: a review," Proceedings of the Indian Academy of Sciences (Animal Science/Plant Science) Supplement, pp. 127-163, 1986.

[32] S. Menon and K. S. Bawa, "Applications of geographic information systems, remote-sensing, and a landscape ecology approach to biodiversity conservation in the western ghats," Current Science, vol. 73, no. 2, pp. 134-145, 1997.

[33] S. Narendra Prasad, L. Vijayan, S. Balachandran, V. S. Ramachandran, and C. P. A. Verghese, "Conservation planning for the western ghats of kerala: i. A gis approach for location of biodiversity hot spots," Current Science, vol. 75, no. 3, pp. 211-219, 1998.

[34] C. S. Jha, C. B. S. Dutt, and K. S. Bawa, "Deforestation and land use changes in Western Ghats, India," Current Science, vol. 79, no. 2, pp. 231-238, 2000.

[35] S. Joseph, G. A. Blackburn, B. Gharai, S. Sudhakar, A. P. Thomas, and M. S. R. Murthy, "Monitoring conservation effectiveness in a global biodiversity hotspot: the contribution of land cover change assessment," Environmental Monitoring and Assessment, vol. 158, no. 1-4, pp. 169-179, 2009.

[36] A. H. Gentry, "Tropical forest biodiversity: distributional patterns and their conservational significance," Oikos, vol. 63, no. 1, pp. 19-28, 1992.

[37] B. R. Ramesh, P. D. Venugopal, R. Pélissier, S. V. Patil, M. H. Swaminath, and P. Couteron, "Mesoscale patterns in the floristic composition of forests in the central western ghats of Karnataka, India," Biotropica, vol. 42, no. 4, pp. 435-443, 2010.

[38] F. Blasco, "Aspects of flora and ecology of the savannas of the South Indian Hills," Journal of the Bombay Natural History Society, vol. 67, pp. 522-534, 1970.

[39] M. P. Nayar, Hotspots of Endemic Plants of India, Tropical Botanic Garden Research Institute, 1996.
[40] S. Joseph, Geospatial characterisation of compositional and functional attributes of tropical forest in Anamalai Hills, Western Ghats, India, Ph.D. thesis, Mahatma Gandhi University, Kerala, India, 2010.

[41] R. J. Hijmans, S. E. Cameron, J. L. Parra, P. G. Jones, and A. Jarvis, "Very high resolution interpolated climate surfaces for global land areas," International Journal of Climatology, vol. 25, no. 15, pp. 1965-1978, 2005.

[42] C. J. F. Ter Braak, "The analysis of vegetation-environment relationships by canonical correspondence analysis," Vegetatio, vol. 69, no. 1-3, pp. 69-77, 1987.

[43] B. McCunne and M. J. Mefford, Multivariate Analysis of Ecological Data Ver: 4.14, MjM Software, Oregon, Ore, USA, 1999.

[44] C. J. F. Ter Braak, "Canonical correspondence analysis: a new eigenvector technique for multivariate direct gradient analysis," Ecology, vol. 67, no. 5, pp. 1167-1179, 1986.

[45] D. C. Montgomery and E. A. Peck, Introduction to Linear Regession Analysis, John Wiley \& Sons, New York, NY, USA, 1982.

[46] C. E. Shannon and W. Weiner, The Mathematical Theory of Communication, University Illinois Press, Urbana, Ill, USA, 1949.

[47] E. H. Simpson, "Measurement of diversity," Nature, vol. 163, no. 4148, article 688, 1949.

[48] SPSS, SPSS for Windows Ver: 11.5, SPSS, Chicago, Ill, USA, 2002.

[49] A. Giriraj, M. S. R. Murthy, and B. R. Ramesh, "Vegetation composition, structure and patterns of diversity: a case study from the tropical wet evergreen forests of the Western Ghats, India," Edinburgh Journal of Botany, vol. 65, no. 3, pp. 447468, 2008.

[50] V. Srinivas and N. Parthasarathy, "Comparative analysis of tree diversity and dispersion in the tropical lowland evergreen forest of Agumbe, Central Western Ghats, India," Tropical Biodiversity, vol. 7, pp. 45-60, 2000.

[51] H. G. Champion and S. K. Seth, A Revised Survey of the Forest Types of India, Manager of Publications, Government of India, New Delhi, India, 1967.

[52] C. J. F. ter Braak, "Ordination," in Data Analysis in Community and Landscape Ecology, R. H. G. Jongman, C. J. F. ter Braak, and O. F. R. van Togeren, Eds., pp. 91-137, Cambridge University Press, New York, NY, USA, 1995.

[53] K. Anitha, S. Joseph, R. J. Chandran, E. V. Ramasamy, and S. N. Prasad, "Tree species diversity and community composition in a human-dominated tropical forest of western ghats biodiversity hotspot, India," Ecological Complexity, vol. 7, no. 2, pp. 217-224, 2010.

[54] N. Ayyappan and N. Parthasarathy, "Biodiversity inventory of trees in a large-scale permanent plot of tropical evergreen forest at varagalaiar, anamalais, Western Ghats, India," Biodiversity and Conservation, vol. 8, no. 11, pp. 1533-1554, 1999.

[55] G. Utkarsh, N. V. Joshi, and M. Gadgil, "On the patterns of tree diversity in the Western Ghats of India," Current Science, vol. 75, no. 6, pp. 594-603, 1998.

[56] H. C. Dawkins, "The volume increment of natural tropical high forest and limitations of improvements," Empire Forestry Review, vol. 38, pp. 175-180, 1959.

[57] T. Ganesh, R. Ganesan, M. Soubadra Devy, P. Davidar, and K. S. Bawa, "Assessment of plant biodiversity at a midelevation evergreen forest of kalakad-mundanthurai tiger reserve, Western Ghats, India," Current Science, vol. 71, no. 5, pp. 379-392, 1996. 
[58] J. P. Pascal and R. Pelissier, "Structure and floristic composition of a tropical evergreen forest in South-West India," Journal of Tropical Ecology, vol. 12, no. 2, pp. 191-214, 1996.

[59] D. Barboni, R. Bonnefille, S. Prasad, and B. R. Ramesh, "Variation in modern pollen from tropical evergreen forests and the monsoon seasonality gradient in SW India," Journal of Vegetation Science, vol. 14, no. 4, pp. 551-562, 2003.

[60] A. H. Gentry, "Neotropical floristic diversity: phytogeographical connections between central and South America, pleistocene climatic fluctuations, or an accident of the andean orogeny?" Annals—Missouri Botanical Garden, vol. 69, no. 3, pp. 557-593, 1982.

[61] A. H. Gentry, "Changes in plant community diversity and floristic composition on environmental and geographical gradients," Annals of the Missouri Botanical Garden, vol. 75, pp. 1-34, 1988.

[62] G. Aplet, R. Hughes, and P. Vitousek, "Ecosystem development on Hawaiian lava flows: biomass and species composition," Journal of Vegetation Science, vol. 9, pp. 17-26, 1998.

[63] N. C. A. Pitman, J. W. Terborgh, M. R. Silman et al., “A comparison of tree species diversity in two upper amazonian forests," Ecology, vol. 83, no. 11, pp. 3210-3224, 2002. 

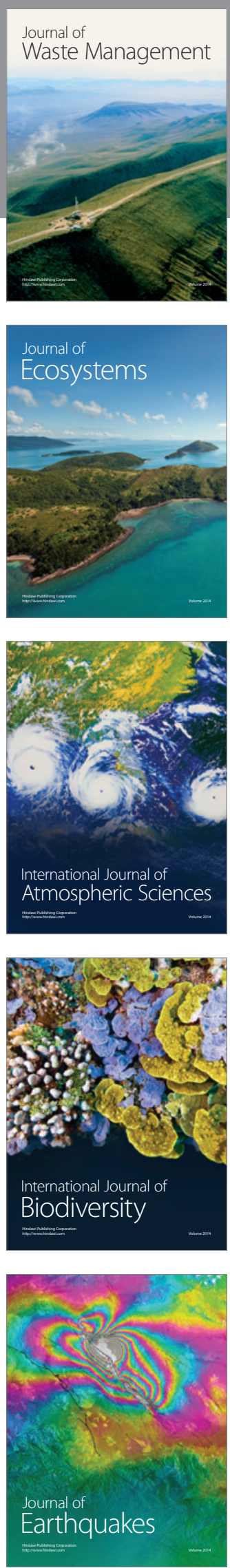
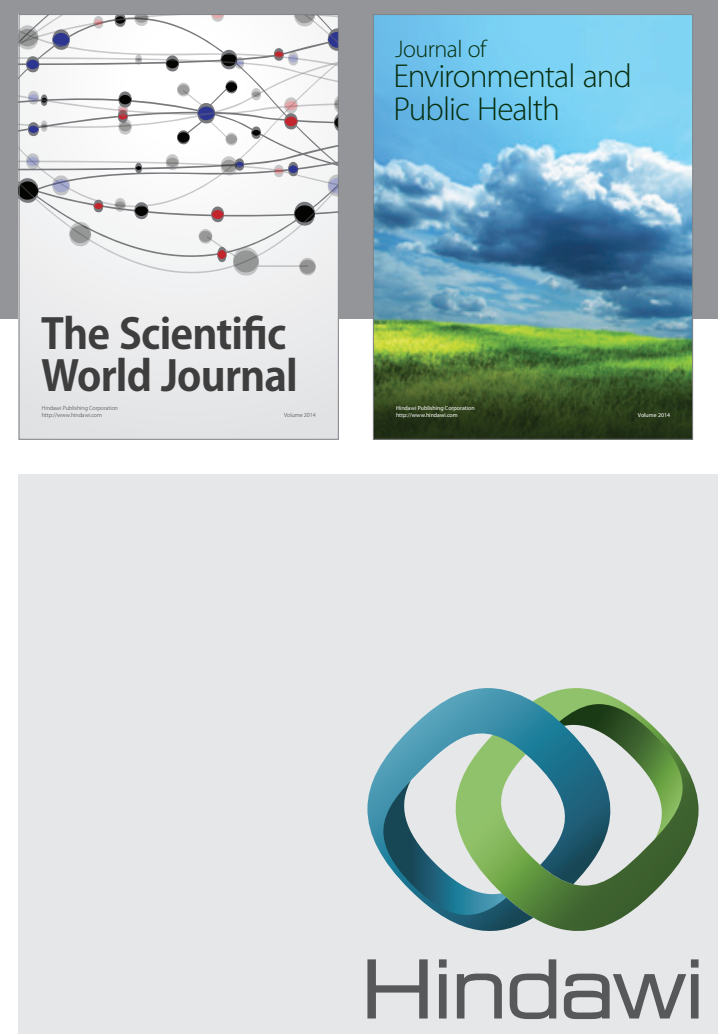

Submit your manuscripts at

http://www.hindawi.com
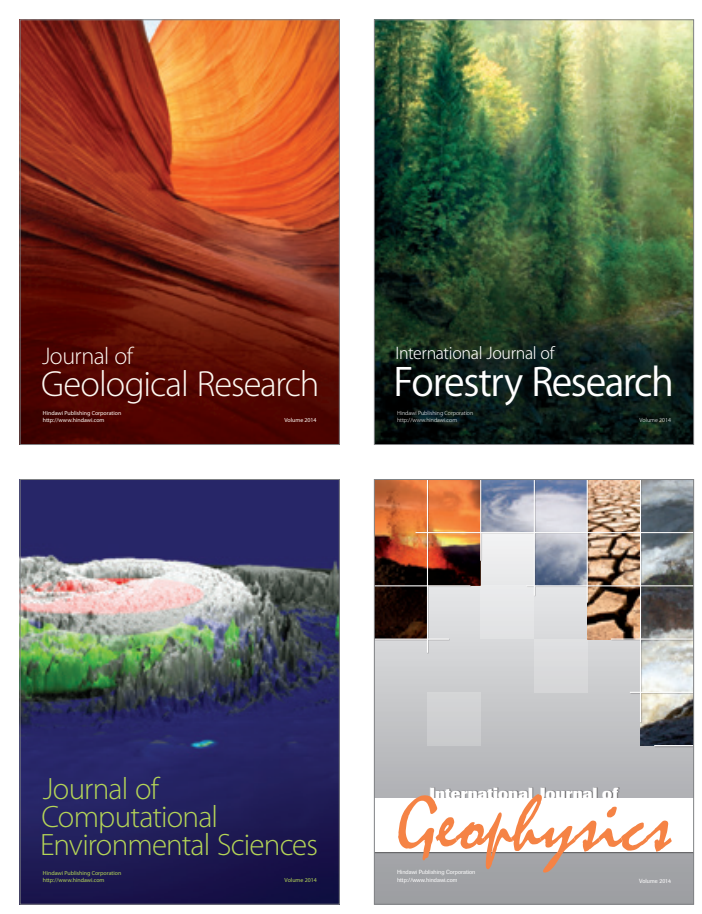
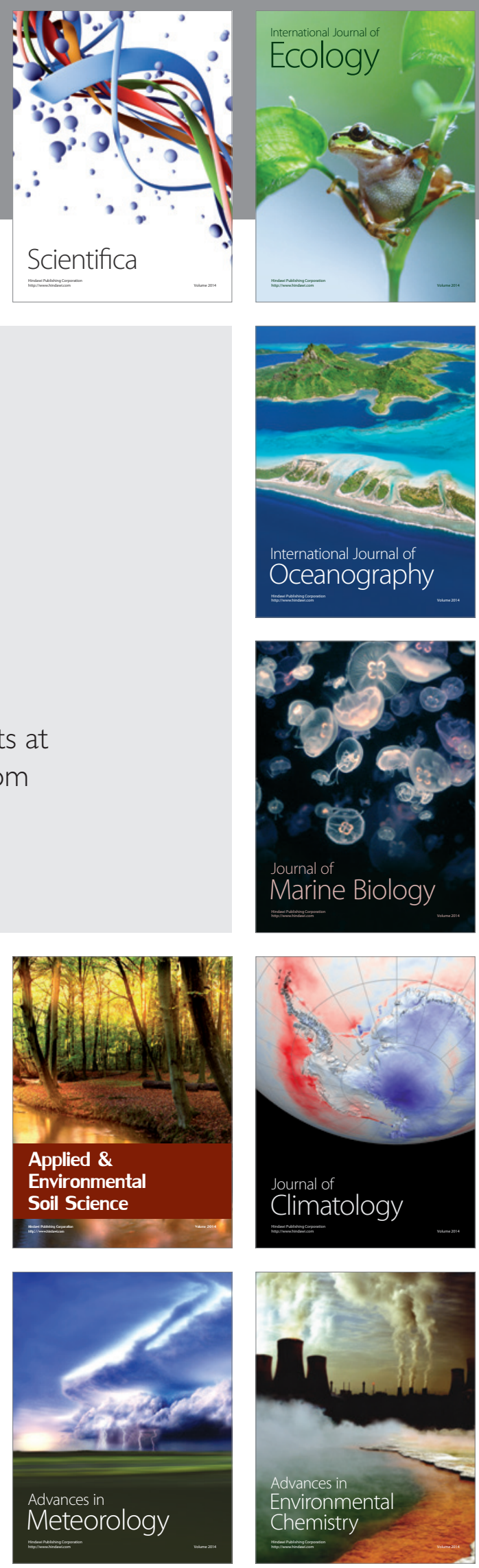